PART II. PHYSICAL ACTIVITY, HEALTH AND QUALITY OF LIFE: A CENTRAL EUROPEAN PERSPECTIVE DZIAŁ II. AKTYWNOŚĆ FIZYCZNA, ZDROWIE I JAKOŚĆ ŻYCIA: PERSPEKTYWA ŚRODKOWOEUROPEJSKA

\title{
A PRELIMINARY STUDY ON THE EFFECT OF THE COVID-19 PANDEMIC ON SPORTING BEHAVIOR, MINDFULNESS AND WELL-BEING
}

\section{WSTĘPNE BADANIE DOTYCZĄCE WPŁYWU PANDEMII COVID-19 NA ZACHOWANIA SPORTOWE, UWAŻNOŚĆ I DOBROSTAN}

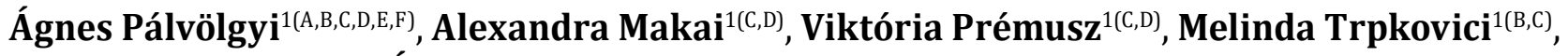 \\ Pongrác Ács $^{1(C, D, G)}$, József Betlehem ${ }^{1(A, D, G)}$, Kata Morvay-Sey ${ }^{1(A, B, C, D, E, F)}$
}

${ }^{1}$ Faculty of Health Sciences, University of Pécs, Hungary

Authors' contribution Wkład autorów:

A. Study design/planning zaplanowanie badań B. Data collection/entry zebranie danych C. Data analysis/statistics dane - analiza i statystyki D. Data interpretation interpretacja danych E. Preparation of manuscript przygotowanie artykułu F. Literature analysis/search wyszukiwanie i analiza literatury G. Funds collection zebranie funduszy

\section{Tables: 0}

Figures: 2

References: 34

Submitted: 2020 Jun 30

Accepted: 2020 Aug 3

\section{Summary}

Background. The COVID-19 pandemic has affected individual well-being negatively; to mitigate the impact, psychological resources are required. Material and methods. Both the WHO WBI-5: 5-item World Health Organization Well Being Index and MAAS: Brown and Ryan (2003) Mindfulness Attention and Awareness Scale were utilized in this study on 827 university students (age 25.29 \pm 8.09 ). Statistical Package IBM SPSS v 24 was used and significance level was set at $\mathrm{p} \leq 0.05$. Results. We found significant positive correlation between dispositional mindfulness and well-being $(\mathrm{R}=0.347 ; \mathrm{p}=0.001)$. Significant differences in mindfulness and well-being were noted between the regularly physically active and non-active groups $(\mathrm{Z}=-2.850 ; \mathrm{p}=0.004 ;$ and $\mathrm{Z}=-2.152 ; \mathrm{p}=0.031$, respectively). The population was subdivided into 3 groups (1) professional athlete; (2) recreational athlete; (3) inactive; we found significant differences in mindfulness (Chi-square value $=14.406 ; p=0.001$ ) and well-being (Chi-square value $=19.341 ; \mathrm{p}<0.001)$ across the group. In paired analysis we found significant differences in mindfulness between groups $1-2(\mathrm{Z}=-2.885 ; \mathrm{p}<0.001), 1-3(\mathrm{Z}=-3.537 ; \mathrm{p}<0.001)$ and $2-3$ $(\mathrm{Z}=-2.130 ; \mathrm{p}=0.033)$. Significant differences in well-being were observed between groups $1-3$ $(\mathrm{Z}=-2.273 ; \mathrm{p}=0.023)$ and $2-3(\mathrm{Z}=-4.235 ; \mathrm{p}<0.001)$. We found significant differences regarding the duration (Chi-square value $=342.856 ; \mathrm{p}<0.001$ ) and number of trainings before and during quarantine (Chi-square value $=214.552 ; \mathrm{p}<0.001$ ). Conclusions. Intensive and regular physical activity facilitates the psychological factors which support individual well-being. Exercising regularly and/or competitively appears to offer a protective effect on mental health.

Keywords: COVID-19, physical activity, well-being, dispositional mindfulness

\section{Streszczenie}

Wprowadzenie. Pandemia COVID-19 miała negatywny wpływ na samopoczucie ludzi. Do złagodzenia jej skutków konieczna jest pomoc psychologiczna. Materiał i metody. Przebadano studentów uniwersytetu (N=827; wiek: $25,29 \pm 8,09)$. W badaniu wykorzystano: (1) WHO WBI5: Pięciowymiarowy Wskaźnik Dobrostanu Światowej Organizacji Zdrowia, (2) MAAS: Brown and Ryan (2003): Skala Uważności, Uwagi i Świadomości oraz (3) pakiet statystyczny IBM SPSS v 24, którego poziom istotności wyniósł $\mathrm{p} \leq 0.05$. Wyniki. Zaobserwowano istotną korelację pozytywna między uważnością dyspozycjonalną a dobrostanem $(R=0,347 ; p=0,001)$. Znaczącą różnicę wykazano między grupą osób regularnie uprawiających aktywność fizyczną a grupą osób nieaktywnych w zakresie uważności $(Z=-2,850 ; p=0.004)$ i dobrostanu $(Z=-2,152 ; p=0,031)$. Próbę podzielono na trzy grupy: (1) zawodowych sportowców; (2) sportowców rekreacyjnych i (3) osoby nieaktywne fizycznie. Różniły się one między sobą w zakresie uważności (chikwadrat=14,406; $\mathrm{p}=0,001$ ) i dobrostanu (chi-kwadrat $=19,341 ; \mathrm{p}<0,001)$. Po połączeniu grup w pary zauważono różnice w uważności grup pierwszej i drugiej $(\mathrm{Z}=-2,885 ; \mathrm{p}<0,001)$, pierwszej i trzeciej $(Z=-3,537 ; p<0,001)$ oraz drugiej i trzeciej $(Z=-2,130 ; p=0,033)$. Różnicę w zakresie dobrostanu odnotowano również między grupami pierwszą i trzecią $(\mathrm{Z}=-2,273 ; \mathrm{p}=0,023)$ oraz drugą i trzecią $(Z=-4,235 ; \mathrm{p}<0,001)$. Zaobserwowano także istotną różnicę między czasem trwania (chi-kwadrat=342,856; $\mathrm{p}<0,001$ ) a liczbą treningów przed kwarantanną i podczas niej (chi-kwadrat=214,552; p<0,001). Wnioski. Intensywna i regularna aktywność fizyczna wspiera czynniki psychologiczne odpowiedzialne za dobrostan jednostki. Regularne albo wyczynowe wykonywanie ćwiczeń chroni zdrowie psychiczne.

Słowa kluczowe: COVID-19, aktywność fizyczna, dobrostan, uważność dyspozycjonalna

Pálvölgyi A, Makai A, Prémusz V, Trpkovici M, Ács P, Betlehem J, et al. A preliminary study on the effect of the COVID-19 pandemic on sporting behavior, mindfulness and well-being. Health Prob Civil. 2020; 14(3): 157-164. https://doi.org/10.5114/hpc.2020.97898

Address for correspondence / Adres korespondencyjny: Ágnes Pálvölgyi, Faculty of Health Sciences, University of Pécs, Vörösmarty Mihály str. 4, 7621 Pécs, Hungary, e-mail: agnes.palvolgyi@etk.pte.hu, phone: +36 72513670

ORCID: Âgnes Pálvölgyi https://orcid.org/0000-0002-4439-1977, Alexandra Makai https://orcid.org/0000-0002-1907-120X

Viktória Prémusz https://orcid.org/0000-0002-4059-104X, Pongrác Ács https://orcid.org/0000-0002-4999-7345,

József Betlehem https://orcid.org/0000-0002-4526-4910, Kata Morvay-Sey https://orcid.org/0000-0001-5468-9358

Copyright: (C) Pope John Paul II State School of Higher Education in Biała Podlaska, Ágnes Pálvölgyi, Alexandra Makai, Viktoria Prémusz, Melinda Trpkovici, Pongrác Ács, József Betlehem, Kata Morvay-Sey. This is an Open Access journal, all articles are distributed under the terms of the Creative Commons Attribution-NonCommercial-ShareAlike 4.0 International (CC BY-NC-SA 4.0) License (http://creativecommons.org/licenses/by-nc-sa/4.0/), allowing third parties to copy and redistribute the material in any medium or format and to remix, transform, and build upon the material, provided the original work is properly cited and states its license. 


\section{Introduction}

Since the outbreak of the novel Coronavirus (2019-nCoV), which was first identified in Wuhan China, at the end of December 2019, the virus has subsequently spread to the rest of the world. After the appearance of COVID-19 on the European continent, the countries and governments activated emergency plans to control the spread of the disease. Owing to the non-specific symptoms in the early stages, and the absence of clear transmission, public health could only be protected through social distancing, which lead to national stay at home orders in many countries (suspending in-person school, travel restrictions, and the introduction of home offices for many). In Hungary the strict stay at home order was regulated by the government decree. The stay at home period lasted from March $28^{\text {th }}$ to May $4^{\text {th }}$ 2020. It was obliged to minimalize social contact and to keep 1.5 meter distance from each other. Only essential travel was permitted, which included going to work, the grocery store, pharmacy and church. During this time it was a requirement to wear masks and sanitize your hands regularly [1]. Initially, governments focused on limiting the spread of the infection, but the consequences of the pandemic, as well as the stay at home order, were not only medical.

Many commentaries and letters indicate the possible long lasting and negative psychological impacts of the novel Coronavirus (2019-nCoV) like depression, insomnia, anxiety, anger, confusion, and post-traumatic stress disorder [2-5]. The World Health Organization (WHO) has also highlighted the negative psychological consequences of the pandemic [6].

\section{Psychological effects of COVID-19}

On an individual level, this situation meant social isolation and quarantine, both of which can have a significant impact on psychological well-being [7]; previously published literature suggests that mental health problems could occur during quarantine $[8,9]$. Brooks et al. reviewed studies which compared psychological outcomes for people quarantined with those not quarantined, and found that being quarantined was a predictor of acute stress disorder, posttraumatic stress symptoms, and depression even 3 years later [7].

Why is COVID-19 a (psychologically) traumatic event? There are many reasons, not least being the fact it is a life-threatening disease, which is transmissible, infectious, and invisible. These factors increase stress levels because the event is perceived as unpredictable and unpreventable. Also, it affects a large part of life - in quarantine people are restricted: (1) in their daily routine, which leads to feeling a loss of freedom, and (2) in their relationships (minimizing contact). For example, in Hungary, shopping time was limited by age zones: from 9-12 in the morning only elderly people (aged 65 and above) could go to the grocery store and pharmacy. The increased stress levels caused by disaster-related experiences can trigger some psychological problems as well, such as depression [10], post-traumatic stress disorder [8], sleeping disorder, or generalized anxiety disorder [11]. It is undeniable that the COVID-19 pandemic affected individual well-being negatively.

\section{Relationship between mindfulness and physical activity}

To maintain individual well-being, psychological resources are needed. Mindfulness means paying attention to the present moment (conscious awareness) and doing this nonjudgmentally [12]. Both physical and mental health benefits of mindfulness have been demonstrated in previous research; mindfulness training, e.g. MBCRMindfulness Based Cognitive Therapy, has been shown to be effective in reducing stress levels, and maintaining health and well-being $[13,14]$. There are only a handful of studies that examine dispositional mindfulness in a non-treatment-seeking sample [14,15]. Trait and state mindfulness differ from each other because dispositional (trait) mindfulness means a level that an individual has during everyday life; state mindfulness means a level of mindfulness which a person reaches immediately after a mindfulness meditation [16]. In their article, Schneider et al. reviewed studies which examined the relationship between trait mindfulness and physical activity; they found that dispositional mindfulness and physical activity have a positive correlation in most of the examined studies [17]. Roberts and Danoff-Burg in their cross-sectional study found that those individuals who have higher mindfulness levels report better perceived health. They also found that daily physical activity levels have a significant and positive association with mindfulness, the extent to which physical activity was enjoyed, as well as the number of days in the past week during which physically active was practiced [18].

Researchers found that participation in sports/physical activity is strongly associated with higher levels of well-being and mental health [19]. "Well-being is commonly defined as the optimal functioning that enables an individual to live an effective life and to accomplish satisfaction in life and genuine happiness" [20]. Physically active individuals generally experience less stress, and have lower levels of depression and anxiety [19]. 
Moreover, physical activity has received attention in recent years as a potential treatment for certain physical problems, e.g. cardiovascular disease, musculoskeletal problems [21], and mental diseases, e.g. low mood [22].

\section{Aim of the study}

The aim of our study was to examine the changes in physical activity among university students as a result of the lockdown. We were also curious about whether physical activity levels affect mental well-being, and whether the level of mindfulness plays a role in the level of well-being.

\section{Hypotheses}

We hypothesized that there is a significant difference between the level of dispositional mindfulness and well-being when comparing athletes and inactive students (H1). We also tested the hypothesis that professional athletes and recreational athletes have significantly higher scores compared to inactive students in both psychological factors (trait mindfulness and well-being) (H2). Our third hypothesis was that, due to the COVID-19 lockdown, the amount of physical activity would decrease during the stay at home order (H3).

\section{Material and methods}

We performed the study using self-report surveys, where the following groups of questions and validated questionnaires were used:

1. self-compiled sociodemographic questionnaire, which asked about general data (gender, residency, marital status, etc.), about the frequency and duration of exercising before and during the stay at home order, and whether or not the subject is a professional athlete, recreational athlete or non-athlete;

2. we used the 5-item World Health Organization (WHO-5) Well Being Index [23]; WHO-5 [24] was derived from the WHO-10 [25], developed as a generic scale without any diagnostic specificity. It was validated in Hungarian by Susánszky et al. [26]. It measures subjective psychological well-being of the past two weeks with 5 items, and is a good screening tool for depression. The Hungarian version, unlike the original scale, uses a 4-point Likert scale (from not at all to always). It has a single factor structure, with a total score; higher scores mean better well-being;

3. Mindful Attention Awareness Scale (MAAS) developed by Brown and Ryan [27], validated in Hungarian (MAAS-H) by Simor et al. [28]. This questionnaire measures dispositional mindfulness, consists of 15 items, forming a single factor structure. Each of the items are stated inversely using a 6-point Likert scale (from almost always to almost never). The questionnaire has a total score with higher scores indicating higher levels of trait mindfulness.

All respondents were volunteers and the questionnaires were anonymous. The Kolmogorov-Smirnov test was used to examine the normality of the data. We used non-parametric statistical methods because of a non-normal distribution. We set the significance level at $p<0.05$. Our study was cross sectional and we used a web-based method (Google Forms - free with a Google account) to maintain social distancing. Moreover, the electronic format is the general preference of the examined age group as opposed to a paper-based questionnaire, so we predicted a higher response rate. According to the descriptive statistics, out of the 827 total respondents who were tested during April-May, (average age: 25.29 \pm 8.09 ; median: 22.00) we had 21.64\% male and 78.36\% female respondents. According to the inclusion criteria, all respondents were adults and active students (BSc, MSc, $\mathrm{PhD}$, postgraduate) of the University of Pécs, Hungary.

Our research is authorized by the Hungarian Scientific and Research Ethics Committee (IV/4599-2/2020/ EKU).

\section{Results}

To examine the psychological factors we used Spearman's correlation and found significant positive correlation between the dispositional mindfulness total score and well-being total score $(R=0.347 ; p=0.001)$ in our sample.

After examining the responding students, we divided the sample into 3 groups based on their level of sporting activity: (1) professional athlete; (2) hobby/recreational athlete; (3) non-athlete/inactive. 
Some selected psychological factors in the context of sporting habits

To examine psychological factors (trait mindfulness and well-being) in relation to physical activity, and to confirm our first hypothesis, we used the Kruskal-Wallis test. We found significant differences among professional athletes, recreational athletes and non-athletes in the total score of dispositional mindfulness (Chi-square value=14.406; $\mathrm{p}=0.001$ ) and the total score of well-being (Chi-square value=19.341; $\mathrm{p}<0.001$ ). We used the Mann Whitney test, and found significant differences between the regularly physically active (both professional and recreational) group and the non-active group in mindfulness $(\mathrm{Z}=-2.850$; $\mathrm{p}=0.004)$ and wellbeing $(Z=-2.152 ; p=0.031)$ total score. We wanted to understand more deeply how the level of physical activity (inactive group, recreational athletes, professional athletes) relates to psychological factors. In order to prove our second hypothesis we measured each group in comparison to the other with the Mann-Whitney U test, and found significant differences in the dispositional mindfulness total score (MAAS) between professional athletes and recreational athletes $(Z=-2.885 ; \mathrm{p}<0.001)$, between professional athletes and inactive group $(Z=-3.537$; $\mathrm{p}<0.001)$ and between the recreational athletes and the inactive group $(Z=-2.130 ; p=0.033)$. The professional athlete group had the highest value $(66.14 \pm 12.83)$, followed by recreational athletes $(58.39 \pm 12.51)$ and the inactive group (56.52 111.97$)$. We examined each group in comparison to the other (inactive group, recreational athletes, professional athletes) with the Mann-Whitney U test and found significant differences in the WHOWBI 5 total score between the inactive group and professional athletes $(\mathrm{Z}=-2.273 ; \mathrm{p}=0.023)$ and between inactive group and recreational athletes $(\mathrm{Z}=-4.235 ; \mathrm{p}<0.001)$, but no significant difference was found comparing recreational athletes and the professional group $(\mathrm{p} \geq 0.05)$. Professional athletes achieved a score of 7.55 \pm 3.26 ;

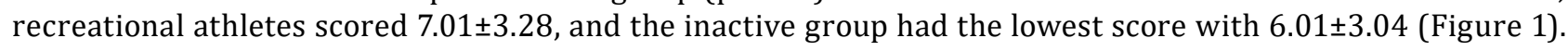
These results mean that we were able to prove our second hypothesis.

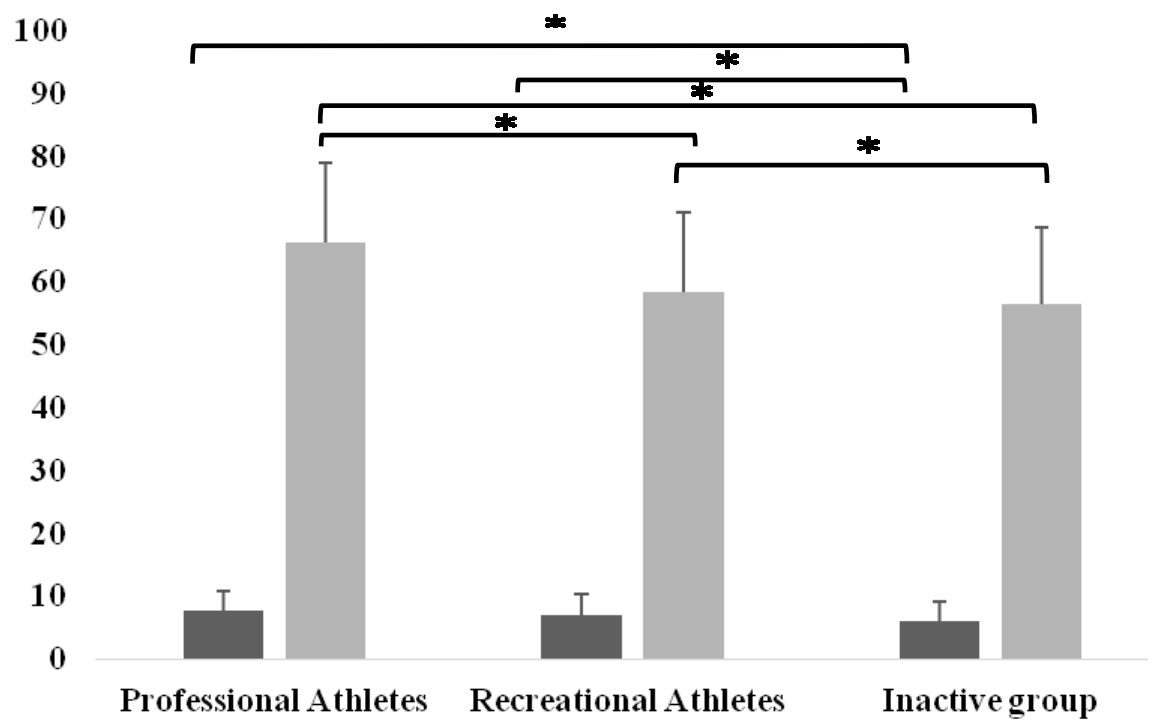

-WHO WBI 5 total score $\quad$ MAAS total score

Figure 1. The mindfulness and well-being total score in relation to the sport categories $(\mathrm{p}<0.05)$

To test the third hypothesis, we examined the amount and duration of physical activity before and during the stay at home order.

\section{The pattern of physical activity before the stay at home order}

Of those who were physically active before the stay at home order, most of them actively participated in sports 1-2 times a week ( $\mathrm{n}=230)$, and there was minimal difference compared to those who participated in sport 3-4 times a week $(n=212)$. Only 74 people answered that they engaged in sports 5 or more times per week. The most common training times were, in order of prevalence, 40-60 minutes, 20-40 minutes, 90 minutes, with the least common response being training that lasted more than 90 minutes. 
The pattern of physical activity during the stay at home order

Of those respondents who were physically active during the stay at home order, most of them participate in sports 3-4 $(n=215)$ or 1-2 $(n=211)$ times a week, which is almost the same as before the stay at home order, but the number of those who engaged in sporting activity 5 or more times per week increased from $n=74$ to $n=159$. In comparison the "before and during stay at home order" duration of the typical training time did not change.

The changes in the amount of physical activity per week can be seen in Figure 2.

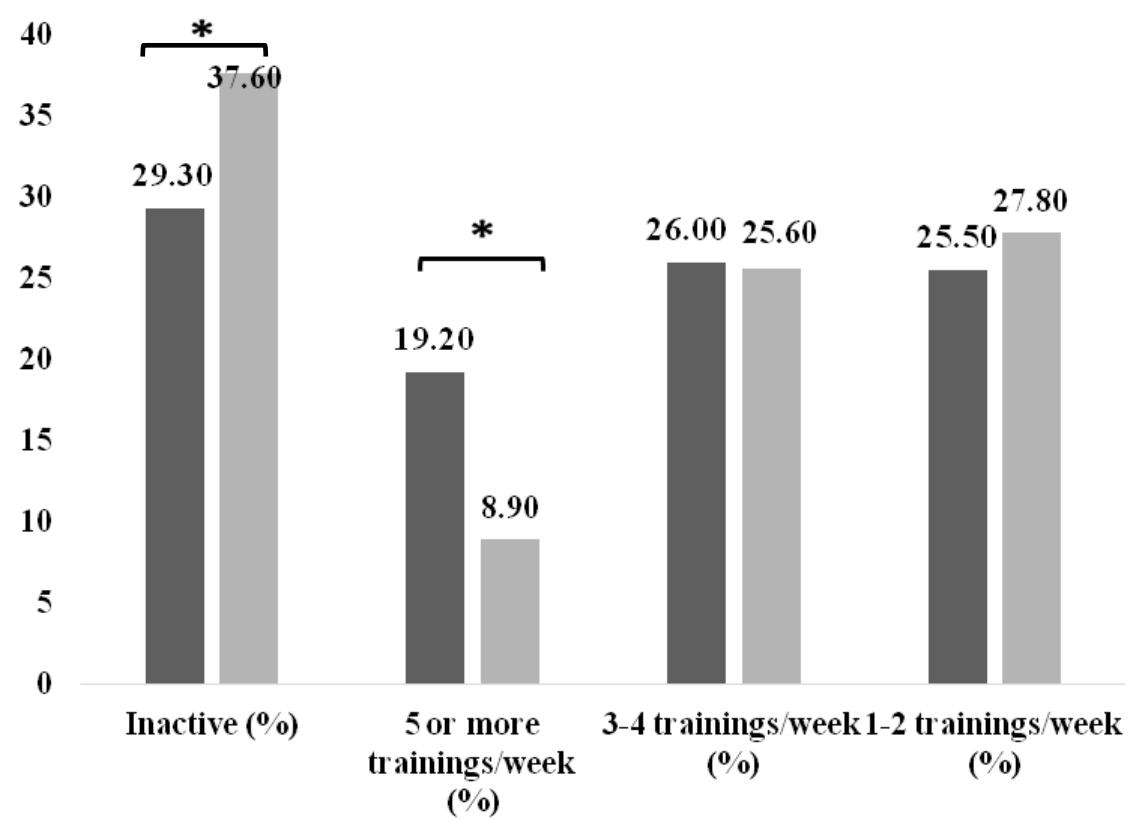

\section{During quarantine Before quarantine}

Figure 2. The weekly physical activity before and during the stay at home order $(\%)(p<0.05)$

We used Wilcoxon rank tests to measure the difference between "before and during stay at home order" in groups. We found only significant difference in the inactive group ( $Z=-4.750 ; p<0.001)$ and in the " 5 or more trainings/week" group ( $\mathrm{Z}=-6.699 ; \mathrm{p}<0.001)$. The biggest increase $(10.3 \%)$ was in the number of those who had training 5 or more times per week, while there was little (not significant) increase in those training 3-4 times per week $(0.4 \%)$. The number of inactives (-8.3\%), and the number of those who train $1-2$ times per week $(-2.3 \%)$, decreased during the stay at home order. Overall, the number of active students increased by $11.8 \%$.

To examine the changes between the pattern of physical activity of the respondents before and during the stay at home order, we used the Pearson Chi-square test and found significant differences among the number of trainings before and during the stay at home order (Chi-square value=214.552; $\mathrm{p}<0.001$ ). We also found significant differences among the duration of trainings (Chi-square value=342.856; $<<0.001$ ).

\section{Discussion}

In our cross-sectional study we examined the sporting behavior of young adults and two psychological factors. These factors are trait mindfulness and well-being, which are known as protective factors in mental health. Trait mindfulness helps people handle distress and improves their satisfaction with life, thus both physical activity and dispositional mindfulness promote well-being. We were curious about whether the difference in sports categories (professional, recreational, or non-athlete) can be seen at the level of mindfulness and well-being. The WHO WBI-5 measures the previous two weeks, so we have results of subjective well-being during lockdown.

We found that mindfulness and well-being have a positive correlation. Our results are in accordance with Mettler et al. [29], where they examined the protective role of trait mindfulness against problematic behaviors (e.g. pathological video gaming). They also used the Mindfulness Attention and Awareness Scale, and found that dispositional mindfulness and elements of subjective well-being are positively associated with one another. We can see that the higher the mindfulness level, the better the subjective well-being of the individual. It is possible 
that mindfulness plays a role in maintaining and improving well-being, despite stressful and demanding situations, but further investigations are needed to see demonstrate this potential nexus. We examined these psychological factors in relation to sporting categories; when we compared the regularly physically active (both professional and recreational) and non-active groups in mindfulness and well-being, we found significant difference. This means that those who practice sports regularly have higher levels of dispositional mindfulness, and thus, during a stressful situation like the COVID-19 pandemic lockdown, they maintained a higher level of well-being; these results are consistent with $\mathrm{H} 1$. We also compared the sporting groups in pairs and the results of the analysis proved $\mathrm{H} 2$. We observed a significant difference in all of the sporting groups in terms of mindfulness, which means that those who participate in sports at a high level (professionally) had the highest scores in mindfulness; recreational athletes had the second highest scores, with the non-active group having the lowest. We found similar results regarding well-being; the group of professional athletes had the highest level of well-being, the recreational group the second highest, and the non-athlete group had the lowest. We observed no significant difference in the well-being of professional athletes compared to recreational athletes. These results suggest that professional athletes have a much higher level of conscious awareness. This could be explained by the fact that competitive sports require a high level of attention and awareness both in lifestyle and in the execution of movements. A professional athlete must concentrate on the present moment, otherwise it is unlikely that they will perform well. We realized that with high mindfulness levels, professional athletes are much more aware of what they do, and this results in much higher levels of well-being. The relationship between dispositional mindfulness and physical activity is still unclear. Ruffault et al. [30] found in their cross-sectional study that as dispositional mindfulness increases, the relation between intrinsic motivation and physical activity becomes stronger. Marques de Abreu et al. [31] found in their investigation that high levels of physical activity implicate subjective pleasure and well-being, which is consistent with our findings.

We investigated the sporting habits of this sample group, including the number and duration of training per week, because according to Ács et al., weekly sports exercise has health benefits [32]. We have preliminary results about the effect of the stay at home order on the changes in physical activity. When comparing the "before and during the stay at home order situation" the duration of the typical training time did not change, but the amount of physical activity per week changed in some ways. The number of students who participated in sports 1-2 times per week decreased, but the number of those who engage in sports 3-4, and 5 times or more per week, increased. We can see that the students of the University of Pécs became less inactive, so our third hypothesis (H3) that physical activity will decrease during the stay at home order was not proven in this sample. CastañedaBabarro et al. [33] stated that physical activity highly decreased during confinement in the Spanish population, and found that both young people and students showed the highest decrease in all physical activities, which is inconsistent with our observations. Physical activity has a major role in mental health, it is beneficial for cognitive function, and improves learning; Wunsch et al. [20] investigated university students during a semester, especially during exam period, which is very stressful, and found that those students who were physically active generally felt better than those who are not active at all. Our results offer some insight in understanding how we can maintain physical and emotional health during a physically restricted period, but further study is required. In Hungary, the only permissible reason to go outside during the stay at home order, other than going to work or the grocery store, was to exercise outside (in the open air) alone [1]. During the stay at home order it could be observed through social media, that the number of free online courses widely increased; so more people could access these resources, many were provided free of charge. Those who previously did not engage in training because of the cost or lack of time, during the "stay at home" period, now had an opportunity to begin. Our sample contained young adults, who use the internet constantly. Since thousands of commentaries can be found online regarding the positive effects of being physically active, it is likely that this generation is much more aware of these things, and therefore may allocate more free time to train.

\section{Limitations and future directions}

The limitation of this study is that it only examined a small section of the population (university students), so the data is not representative of society as a whole, thus we cannot draw general conclusions. In line with previous research the survey respondents are more likely to be female than male [34], moreover at the University of Pécs, the gender distribution is 59,05\% female and 40,95\% male. Our previous experience also points to the fact that women have stronger willingness to take part in surveys than men. The current pandemic situation is unique, so there is little or no literature in this topic, which makes the discussion of the results more difficult. According to forecasts on the virus, additional waves are to be expected, so in the future it would be worthwhile to further investigate the psychological reactions related to the spread of the virus and possible lockdown, as well as growing fears about the future. 


\section{Conclusions}

The present study examined the sporting behavior of university students, their dispositional mindfulness and well-being. The results showed that professional athletes had higher levels of mindfulness, and experienced higher levels of well-being during an emotionally demanding situation. The COVID-19 pandemic and the accompanying lockdown have no doubt affected everyone's life in some stressful way. From our results it can be seen that exercising, regularly or competitively, can help protect mental health during stressful situations.

\section{Disclosures and acknowledgements}

This research was partially supported by the Human Resource Development Operational Program, grant No.: HRDOP-3.6.2-16-2017-00003, Cooperative Research Network in Economy of Sport, Recreation and Health. The authors declare that they have no competing interests.

\section{References:}

1. [Government Decree no. 71/2020 of 27 March 2020 on the restrictions (Official Journal of Hungary 2020, No. 56)] (in Hungarian).

2. Kumar A, Rajasekharan Nayar K. COVID 19 and its mental health consequences. J Ment Health. Forthcoming 2020. https://doi.org/10.1080/09638237.2020.1757052

3. Venkatesh A, Edirappuli S. Social distancing in Covid-19: what are the mental health implications?. BMJ. 2020 April 6; 369: m1379. https://doi.org/10.1136/bmj.m1379

4. Santos CF. Reflections about the impact of the SARS-COV-2/COVID-19 pandemic on mental health. Braz J Psychiatry. Forthcoming 2020. https://doi.org/10.1590/1516-4446-2020-0981

5. Lieberman JA, Olfson M. Meeting the mental health challenge of the COVID-19 pandemic [Internet]. East Windsor: Psychiatric Times; 2020 Apr 24 [2020 Jun 20]. Available from: https://www.psychiatrictimes. com/view/meeting-mental-health-challenge-covid-19-pandemic

6. World Health Organization. Mental health and psychosocial considerations during the Covid-19 outbreak [Internet]. Geneva: World Health Organization; 2020 March 18 [cited 2020 Jun 20]. Available from: https://www.who.int/publications/i/item/WHO-2019-nCoV-MentalHealth-2020.1

7. Brooks SK, Webster RK, Smith LE, Woodland L, Wessely S, Greenberg N, et al. The psychological impact of quarantine and how to reduce it: rapid review of the evidence. Lancet. 2020; 395: 912-920. https://doi.org/10.1016/S0140-6736(20)30460-8

8. Hawryluck L, Gold WL, Robinson S, Pogorski S, Galea S, Styra R. SARS control and psychological effects of quarantine. Emerg Infect Dis. 2004; 10(7): 1206-1212. https://doi.org/10.3201/eid1007.030703

9. Lee SM, Kang WS, Cho AR, Kim T, Park JK. Psychological impact of the 2015 MERS outbreak on hospital workers and quarantined hemodialysis patients. Compr Psychiatry. 2018 Nov; 87: $123-127$. https://doi.org/10.1016/j.comppsych.2018.10.003

10. Liu X, Kakade M, Fuller CJ, Fan B, Fang Y, Kong J, et al. Depression after exposure to stressful events: lessons learned from the SARS epidemic. Compr Psychiatry. 2012; 53(1): 15-23.

https://doi.org/10.1016/j.comppsych.2011.02.003

11. Huang Y, Zhao N. Chinese mental health burden during the COVID-19 pandemic. Asian J Psychiatr. 2020 Jun; 51: 102052. https://doi.org/10.1016/j.ajp.2020.102052

12. Kabat-Zinn J. Wherever you go, there you are. New York: Hyperion; 2005.

13. Grossman P, Tiefenthaler-Gilmer U, Raysz A, Kesper U. Mindfulness training as an intervention for fibromyalgia: evidence of postintervention and 3-year follow-up benefits in well-being. Psychother Psychosom. 2007; 76: 226-233. https://doi.org/10.1159/000101501

14. Rohanszky M, Berenyi K, Fridrik D, Pusztafalvi H. [Effectiveness of mindfulness-based cancer recovery (MBCR) program among Hungarian cancer patients]. Orv Hetil. 2017; 158(33): 1293-1301 (in Hungarian). https://doi.org/10.1556/650.2017.30817

15. Eddy P, Wertheim EH, Hale MW, Wright BJ. Trait mindfulness helps explain the relationships between job stress, physiological reactivity and self-perceived health. Journal of Occupational and Environmental Medicine. 2019; (61)1: 12-18. https://doi.org/10.1097/J0M.0000000000001493

16. Murphy MJ, Mermelstein LC, Edwards KM, Gidycz CA. The benefits of dispositional mindfulness in physical health: a longitudinal study of female college students. J Am Coll Health. 2012; 60(5): $341-348$. https://doi.org/10.1080/07448481.2011.629260 
17. Schneider J, Malinowski P, Watson PM, Lattimore P. The role of mindfulness in physical activity: a systematic review. Obes Rev. 2019; 20(3): 448-463. https://doi.org/10.1111/obr.12795

18. Roberts KC, Danoff-Burg S. Mindfulness and health behaviors: is paying attention good for you?. J Am Coll Health. 2010; 59(3): 165-73. https://doi.org/10.1080/07448481.2010.484452

19. McMahon EM, Corcoran P, O’Regan G, Keeley H, Cannon M, Carli V, et al. Physical activity in European adolescents and associations with anxiety, depression and well-being. Eur Child Adolesc Psychiatry. 2017; 26: 111-122. https://doi.org/10.1007/s00787-016-0875-9

20. Wunsch K, Kasten N, Fuchs R. The effect of physical activity on sleep quality, well-being, and affect in academic stress periods. Nat and Sci Sleep. 2017; 9: 117-126. https://doi.org/10.2147/NSS.S132078

21. Nakahara H, Ueda SY, Miyamoto T. Low-frequency severe-intensity interval training improves cardiorespiratory functions. Med Sci Sports Exerc. 2015; 47(4): 789-798. https://doi.org/10.1249/MSS.0000000000000477

22. Szabó A, Ábrahám J. [Three minutes of light exercise improves well-being]. Magyar Sporttudományi Szemle. 2012; 13(51): 27-30 (in Hungarian).

23. Topp CW, Østergaard SD, Søndergaard S, Bech P. The WHO-5 Well Being Index: a systematic review of the literature. Psychother Psychosom. 2015; 84: 167-176. https://doi.org/10.1159/000376585

24. Bech P. The Bech, Hamilton and Zung Scales for mood disorders: screening and listening. 2nd edition. Berlin: Springer; 1996. https://doi.org/10.1007/978-3-642-61169-8

25. Bech P, Staehr-Johansen K, Gudex C. The WHO (Ten) Well-Being Index: validation in diabetes. Psychother Psychosom. 1996; 65(4): 183-190. https://doi.org/10.1159/000289073

26. Susánszky É, Konkoly Thege B, Stauder A, Kopp M. [The Hungarian validation of the WHO Well-Being Inventory (WBI-5) short form based on the health survey of Hungarostudy 2002]. Mentálhigiéné és Pszichoszomatika. 2006; 7(3): 247-255 (in Hungarian). https://doi.org/10.1556/Mental.7.2006.3.8

27. Brown KW, Ryan RM. The benefits of being present: mindfulness and its role in psychological well-being. J Pers Soc Psychol. 2003; 84(4): 822-848. https://doi.org/10.1037/0022-3514.84.4.822

28. Simor P, Petke Z, Köteles F. Measuring pre-reflexive consciousness: the Hungarian validation of the mindful attention awareness scale (MAAS). Learn Percept. 2013; 5(2): 17-29. https://doi.org/10.1556/LP.5.2013.Suppl2.2

29. Mettler J, Mills DJ, Heath NL. Problematic gaming and subjective well-being: how does mindfulness play a role?. Int J Ment Health Addiction. 2020; 18: 720-736. https://doi.org/10.1007/s11469-018-9978-5

30. Ruffault A, Bernier M, Juge N, Fournier JF. Mindfulness may moderate the relationship between intrinsic motivation and physical activity: a cross-sectional study. Mindfulness (NY). 2016; 7(2): 445-452. https://doi.org/10.1007/s12671-015-0467-7

31. Marques de Abreu J, Andrade de Souza R, Gomes Viana-Meireles L, Landeira-Fernandez J, Filgueiras A. Effects of physical activity and exercise on well-being in the context of the Covid-19 pandemic. MedRXiv. Forthcoming 2020. https://doi.org/10.1101/2020.06.08.20125575

32. Ács P, Prémusz V, Morvay-Sey K, Kovács A, Makai A, Elbert G. [Changes of sport and physical activity indicators in Hungary and in the European Union according to the results from recent years]. Sport-és Egészségtudományi Füzetek. 2018; 2(1): 65-80 (in Hungarian).

33. Castañeda-Babarro A, Arbillaga-Etxarri A, Gutiérrez-Santamaria B, Coca A. Impact of COVID-19 confinement on the time and intensity of physical activity in the Spanish population. Res Sq. Forthcoming 2020. https://doi.org/10.21203/rs.3.rs-26074/v1

34. Porter RS, Whitcomb EM. Non-response in student surveys: the role of demographics, engagement and personality. Research in Higher Education. 2005; 46(2): 127-152. https://doi.org/10.1007/s11162-004-1597-2 